\title{
Leading article: Idiotypes and anti-idiotypes: What are they trying to tell us?
}

A cardinal feature of the immune system is its ability to generate an enormous number of different antibodies (approximately 100 million in the mouse). ${ }^{1}$ Antibodies are classically identified by their antigen binding properties. A second method of describing antibodies serologically is by an analysis of their idiotypes. The variable (V) region of the immunoglobulin molecule was first shown to be antigenic by the injection of $\mathrm{V}$ region polypeptides into experimental animals. ${ }^{2}$ These antigenic determinants are known as idiotopes and collectively comprise the idiotype. The three dimensional shape of the idiotype may involve structures on either the heavy or light chains or both. Idiotypes can be divided into two main types based on their precise location within the variable region: $(a)$ those located at the antigen binding site (known as paratopes) and (b) those adjacent to it (known as framework determinants). Antibodies (anti-idiotypes) may be raised against idiotypes in either the same or different species by suitable immunisation. Furthermore, it is evident that the immune system may provide its own anti-idiotypes. Anti-idiotypes binding to the paratope will inhibit binding of the antigen to antibodies bearing the homologous idiotype, whereas those against framework determinants will not usually do so. Idiotypes may be restricted to a particular immunoglobulin molecule-a private idiotype, or appear on antibodies of different antigen binding specificity-a common or public idiotype. Idiotypes represent the phenotypic products of variable (V) region genes, and analysis of idiotypes permits study of the genetic relation between antibodies.

Consideration of idiotype-anti-idiotype interactions led Jerne to propose the network theory. ${ }^{3}$ Stimulation of the immune system by antigen results in a cascade with formation of antibody 1 (Ab1), which in turn induces formation of anti-idiotype antibody $2(\mathrm{Ab} 2)$, which has its own anti-idiotype antibody $\mathrm{Ab} 3$. These three antibodies and antigen can form a simple circuit because $\mathrm{Ab} 1$ and $\mathrm{Ab} 3$ may have structural similarity. In the mouse immunisation with the synthetic random polymer $\left(\mathrm{Glu}^{60} \mathrm{Ala}^{30}\right.$ $\left.\mathrm{Tyr}^{10}\right)(\mathrm{GAT})$ induces formation of the idiotype cascade Ab1 (anti-GAT), Ab2 (anti-idiotype), and Ab3 (anti-anti-idiotype). It has been shown by isolation and sequencing of immunoglobulin $V_{H}$ genes in the GAT system that a single $\mathrm{V}_{\mathrm{H}}$ germline gene accounts for the expressed $V_{H}$ sequences of
$\mathrm{Ab} 1$ and $\mathrm{Ab} 3$ antibodies and that immunisation with $\mathrm{Ab} 2$ preferentially stimulates direct expression of $\mathrm{V}_{\mathrm{H}}$ germline genes. ${ }^{4}$ Furthermore, Ab2 may bear structural similarity to the stimulating antigen because the combining site of Ab1 will be complementary to a structure on the antigen and the combining site on $\mathrm{Ab} 2$ will be complementary to that on Ab1. The amino acid sequence of reovirus haemagglutinin (antigen) has a region of sequence homology with the light chain of anti-anti-haemagglutinin (anti-idiotype Ab2). ${ }^{5}$ The immune system may therefore have within the idiotype network an internal image of potential antigens available before meeting an antigen for the first time. This notion is being extensively investigated to determine whether anti-idiotypes may have a role as vaccines. In particular, this approach is being explored as a possible method of vaccination against human immunodeficiency virus (HIV) infection. Monoclonal anti-CD4 (the CD4 antigen is an essential component of the cell surface receptor for $\mathrm{HIV}^{6}$ ) is used to induce an anti-idiotype which mimics the molecular structure of the CD4 molecule and thereby neutralises HIV. ${ }^{7}$ The potential advantages of this approach include the ability of anti-idiotypes to act as surrogate antigens without attendant infection or adjuvant risk problems. Anti-idiotypes could also in theory be manufactured easily in large amounts. There are additional theoretical reasons for thinking that anti-idiotypes may stimulate a more effective cytotoxic $T$ cell response than inactivated virus.

As idiotypes, composed of several idiotopes, are present on the surface of $B$ cells, $T$ helper and $T$ suppressor cells, a mechanism for regulation of the immune system is evident. Both enhancement and suppression of idiotypes in response to anti-idiotype have been demonstrated (reviewed in ref 8 ). Reciprocal changes in idiotype and anti-idiotype have been demonstrated in man after booster immunisation with tetanus toxoid, ${ }^{9}$ and there is some evidence that idiotype-anti-idiotype interaction may play a part in maternal suppression of fetal rejection. ${ }^{\text {(0 }}$ In a single patient with systemic lupus erythematosus (SLE) reciprocal changes in levels of anti-DNA antibodies and anti-idiotypic antibodies have been shown to occur, with the anti-idiotype appearing as the patient went into remission. ${ }^{11}$ Abdou et al also demonstrated in vitro suppression of serum antiDNA antibody binding to DNA by anti-idiotype in 
SLE. ${ }^{12}$ Similarly, anti-idiotype activity to rheumatoid factor (RF) and RF levels have been shown to be reciprocally related in a patient with a monoclonal IgM gammopathy with RF activity and pneumococcal pneumonia. ${ }^{3}$

Cross reactive idiotypes have been reported on many human autoantibodies (reviewed in ref 14), including anti-DNA autoantibodies, ${ }^{15}$ anti-Sm antibodies, ${ }^{16}$ antiacetylcholine receptor antibodies, ${ }^{17}$ and antithyroglobulin antibodies. ${ }^{18}$ Furthermore, amino acid sequence homology has been found between the light chains of human hybridoma derived lupus antibodies bearing a public 16/6 idiotype and a Waldenstrom IgM protein that binds to the klebsiella K30 antigen. ${ }^{19}$ Such cross reactivity suggests a mechanism for initiation of autoimmunity through perturbation of the idiotype network. In the rabbit experimental myasthenia gravis and antiacetylcholine receptor antibodies can be induced by immunisation with a synthetic ligand of the receptor. ${ }^{20}$ Viruses $^{21}$ and bacteria have both been proposed as initiators of an idiotypic cascade resulting in autoimmunity.

Spontaneous autoanti-idiotypes have been described in both organ specific and non-organ specific autoimmune diseases, including mixed cryoglobulinaemia, ${ }^{22}$ IgA deficiency (anti-anticasein antibodies), ${ }^{23}$ myasthenia gravis (anti-antiacetylcholine receptor antibodies) ${ }^{24}$ rye sensitivity (anti-anti-rye 1 antibodies), ${ }^{25}$ and insulin dependent diabetes mellitus (anti-anti-insulin receptor antibodies). ${ }^{26}$ The widespread existence of autoanti-idiotypes suggests that they are important in terms of immunoregulation and that they may be involved in the pathogenesis of autoimmunity.

Further evidence that perturbation of the idiotype network can have deleterious effects has been provided by Mendlovic et al, who injected C3H.SW female mice (a non-autoimmune prone strain) with human monoclonal antibodies bearing the public $16 / 6$ idiotype. ${ }^{27}$ High levels of murine anti-16/6 and anti-anti-16/6 antibodies (resembling anti-DNA antibodies) were detected in the sera of the immunised mice. High titres of antibodies to DNA, Sm, RNP, Ro, and cardiolipin were noted, as were immune complexes in the kidneys which contained the 16/6 idiotype. Injection of a common idiotype thus appears to have induced a lupus-like disease. ${ }^{27}$

The existence of cross reactive idiotypes on autoantibodies from unrelated people and on antibodies binding foreign antigens suggests that highly conserved germline genes may be involved and that they arise from a restricted number of $\mathrm{V}$ genes. Datta et al have shown that the cross reactive idiotype $16 / 6$, originally described on a human monoclonal anti-DNA antibody, is present in nor- mal individuals. ${ }^{28}$ Fong and coworkers showed tha most RF light chains from patients with rheumatoi®. arthritis possess a cross reactive idiotype (designated? PSL2) but not two other cross reactive idiotype $\overline{\bar{s}}$ (PSL3 and 17-109). ${ }^{29}$ In contrast, elderly peoples and patients with Sjögren's syndrome bore all three and they suggested that this represents somatio, diversification of a common $\mathrm{RF}$ light chain $\mathrm{V} \overrightarrow{\mathrm{B}}$ gene(s) or, alternatively, use of multiple possiblü related $V_{k}$ gene segments. ${ }^{29}$ Sequence analysis of anti-DNA antibodies derived from hybridomas fron $\vec{P}$ patients with SLE and leprosy has shown that those bearing the 16/6 idiotype are products of the $V_{\mathbb{P}}^{\omega}$ germline gene $V_{H} 26$ (a member of the $V_{H}$ III gene family), whereas those bearing another idiotype $21 / 28$, are products of a different $V_{H}$ germline gene. ${ }^{30}$ Thus unmutated germline genes can encode autoantibodies. Similar results have been reporte\& for human RF. ${ }^{31}{ }^{32}$ It seems increasingly likely thad far from 'horror-autoxicus' autoantibodies are products of the normal human immunoglobulins repertoire and often detectable in healthy subjectso The stimulation leading to their expansion and thei precise role in immunopathology are unknown.

Modulation of the immune system with idiotype or anti-idiotypes has been proposed as a therapeutic approach in the management of SLE. In lupus preneo mice anti-idiotype administration has been showete suppress both production of anti-DNA antibodies and nephritis. The effect was transient, however and anti-DNA antibodies appeared that did not beap the idiotype. ${ }^{33}$ Zouali et al innoculated mice with syngeneic anti-DNA IgG and muramyl dipeptide (an immunoadjuvant) and found that anti-DN antibody levels were suppressed and that an antis idiotype antibody specific for the injected IgG appeared. ${ }^{34}$ Conjugation of anti-idiotype to a cyto toxic agent (neocarzinostatin) has been shown tक्ष eliminate anti-DNA antibody producing cells iō vivo. ${ }^{35}$ Similar results have been obtained in vitro using conjugates of the $A$ chain of ricin and antio idiotype to inhibit antibody response to acety $\beta$ choline receptor. ${ }^{36}$ Down regulation of a group of public idiotypes, such as those recently identified on anti-DNA, anti-Ro, and anti-Sm antibodies, ${ }^{37}$ ma be an effective means of down regulating autoanti body production. This response may provide the fine tuning needed by the immune system to rids itself of unwanted autoantibodies and provide therapeutic approach without the dangers of cono ventional intensive immunosuppressive therapy Perhaps plasma exchange coupled with passage of plasma over anti-idiotype columns could one day bẹ a feasible proposition.

In conclusion, analysis of idiotypes and antio idiotypes is casting light on the genetic origins o\$ 
autoimmunity and the interrelations of antibodies of various specificities, and may through manipulation of these interactions lead to new treatments.

Bloomsbury Rheumatology Unit,

R A WATTS*

Dept of Rheumatology Research,

D A ISENBERG

University College and

Middlesex Hospital Medical School

${ }^{*}$ Correspondence to Dr R A Watts, Bloomsbury Rheumatology Unit, Arthur Stanley House, 40-50 Tottenham Street, London W1P 9PG.

\section{References}

1 Jerne N K. Idiotypic networks and other preconceived ideas. Immunol Rev 1984; 79: 5-24.

2 Kunkel H G. Mannick M, Williams R C. Individual antigenic specificity of isolated antibodies. Science 1963; 140: 1218-9.

3 Jerne N K. Towards a network theory of the immune system. Annales d'Immunologie (Paris) 1974; 125c: 373-89.

4 Schiff C, Milili M, Hue I, Rudikoff S, Fougereau M. Genetic basis for expression of the idiotypic network: one unique $\operatorname{Ig} \mathrm{V}_{\mathrm{H}}$ germline gene accounts for the major family of $\mathrm{Abl}$ and $\mathrm{Ab3}$ (Ab1') antibodies of the GAT system. $J$ Exp Med 1986; 163: 573-87.

5 Bruck C, Co M S, Slaoui M, et al. Nucleic acid sequence of an internal image-bearing monoclonal antiidiotype and its comparison to the sequence of the external antigen. Proc Natl Acad Sci USA 1986; 83: 6578-82.

6 Dalgleish A G, Besgley P C L, Clapham P R. Crawford D H, Greaves M F, Weiss R A. The CD4 (T4) antigen is an essential component of the receptor for the AIDS retrovirus. Nature 1984; 313: 763-6.

7 Capra J D, Bona C. Idiotypes: practical advances from fundamental concepts. Immunology Today 1988; 9: 98-100.

8 Rajewsky K. Takemori T. Genetics, expression and function of idiotypes. Annu Rev Immunol 1983; 1: 569-607.

9 Geha R S. Presence of auto-antiidiotypic antibody during the normal human immune response to tetanus toxoid antigen. J Immunol 1982; 129: 139-44.

10 Anonymous. Maternal blocking antibodies, the fetal allograft. and recurrent abortion. [Editorial] Lancet 1983; ii: 1175-6.

11 Zouali M. Eyquem A. Idiotypic/antiidiotypic interaction in systemic erythematosus: demonstration of oscillatory levels of anti-DNA autoantibodies and reciprocal antiidiotypic activity in a single patient. Annales d'Immunologie (Paris) 1983; 134c: $377-91$.

12 Abdou N I, Wall H, Lindsley H B, Halsey J F. Suzuki T. Network theory in autoimmunity. In vitro suppression of serum anti-DNA antibody binding to DNA by antiidiotypic antibody in systemic lupus erythematosus. J Clin Invest 1981: 67: 1297-304.

13 Abe T. Takeuchi T. Kiyotaki M. et al. Anti-idiotypic antibodies in a patient with monoclonal rheumatoid factor after pneumococcal bacteraemia. J Immunol 1984; 132: 2381-5.

14 Horsfall A C. Isenberg D A. Idiotypes and autoimmunity: a review of their role in human disease. Journal of Autoimmunity 1988: 1: $7-30$.

15 Shoenfeld Y. Isenberg D A, Rauch J. Madaio M P, Stollar B D, Schwartz R S. Idiotypic cross reactions of monoclonal human lupus autoantibodies. J Exp Med 1983; 158: 718-30.

16 Pisetsky D S. Lerner E A. Idiotypic analysis of a monoclonal anti-Sm antibody. J Immunol 1982; 129: 1489-92.

17 Lefvert A K. James R W, Alliod C. Fulpius B W. A monoclonal anti-idiotypic antibody against anti-receptor antibodies from myasthenic sera. Eur J Immunol 1982; 12: 790-2.

18 Delves $\mathrm{P}$ J, Roitt I M. Idiotypic determinants on human thyroglobulin autoantibodies derived from the serum of Hashimoto patients and EB virus transformed cell lines. Clin Exp Immunol 1984; 57: 33-40.

19 Atkinson P M, Lampman G W, Furie B C, et al. Homology of the $\mathrm{NH} 2$ terminal amino acid sequences of the heavy and light chains of human monoclonal lupus autoantibodies containing the dominant 16/6 idiotype. J Clin Invest 1985; 75: 1138-43.

20 Wassermann N H, Penn A S, Freimuth P I, et al. Anti-idiotypic route to acetylcholine receptor antibodies and experimental myasthenia gravis. Proc Natl Acad Sci USA 1982: 79: 4810-4.

21 Plotz $\mathrm{P} \mathrm{H}$. Autoantibodies are antiidiotypic antibodies to antiviral antibodies. Lancet 1983; ii: 824-6.

22 Geltner D, Franklin E C. Frangione B. Antiidiotypic activity in the IgM fractions of mixed cryoglobulins. J Immunol 1980; 125: $1530-5$.

23 Cunningham-Rundles C. Naturally occurring anti-idiotypic antibodies: participation in immune complex formation in selective IgA deficiency. $J$ Exp Med 1982; 155: 711-9.

24 Dwyer D S, Bradley R J, Urquhart C K. Kearney J F. Naturally occurring antiidiotypic antibodies in myasthenia gravis patients. Nature 1983; 301: 611-4.

25 Bose R, March D G, Duchateau J, Sehan A H, Delespesse G. Demonstration of autoantiidiotypic antibody cross-reacting with public idiotypic determinants in the serum of rye-sensitive allergic patients. J Immunol 1984; 133: 2474-8.

26 Schoelson S E, Marshall S, Horikoshi H, Kolterman O G, Rubenstein A H, Olefsky J M. Antiinsulin receptor antibodies in an insulin dependent diabetic may arise as autoantiidiotypes. $J$ Clin Endocrinol Metab 1986; 63: 56-61.

27 Mendlovic S, Brocke S, Shoenfeld Y, et al. Induction of a systemic lupus erythematosus-like disease in mice by a human common anti-DNA idiotype. Proc Natl Acad Sci USA 1988; 85: $2260-4$.

28 Datta S K. Naparstek Y, Schwartz R S. In vitro production of an anti-idiotype by lymphocytes of normal subjects and patients with systemic lupus erythematosus. Clin Immunol Immunopathol 1986: 38: 302-18.

29 Fong S, Chen P P, Gilbertson T A. Weber J R, Fox R I, Carson $D A$. Expression of three cross reactive idiotypes on rheumatoid factor autoantibodies from patients with autoimmune diseases and seropositive adults. $J$ Immunol 1986; 137: 122-8.

30 Dersimonian H, Schwartz R S, Barrett K J. Stollar B D. Relationship of human variable region heavy chain germline genes to genes encoding antiDNA autoantibodies. J Immunol 1987; 139: 2496-501.

31 Chen P P, Albrandt K, Orida N K, et al. Genetic basis for the cross reactive idiotypes on the light chains of human IgM antiIgG autoantibodies. Proc Natl Acad Sci USA 1986; 83: 8318-22.

32 Radoux V. Chen P P. Sorge J A. Carson D A. A conserved human germline $V_{k}$ gene directly encodes rheumatoid factor light chains. J Exp Med 1986; 164: 2119-24.

33 Hahn B H. Ebling F M. Suppression of murine lupus nephritis by administration of an anti-idiotypic antibody to anti-DNA. $J$ Immunol 1984; 134: 187-90.

34 Zouali M. Jolivet M. Leclerc C, et al. Suppression of murine lupus autoantibodies to DNA by administration of muramyl dipeptide and syngeneic anti-DNA IgG. J Immunol 1985; 135: 1091-6.

35 Sasaki T, Muryoi T. Takai O, et al. Selective elimination of anti-DNA antibody producing cells by antiidiotypic antibody conjugated with neocarzinostatin. J Clin Invest 1986; 77: 1382-6.

36 De Shambo R M. Krolick K A. Selective inhibition of an antibody response to purified acetylcholine receptor using antiidiotypic antibodies coupled to the $A$ chain of ricin. J Immunol 1986; 137: 3135-9.

37 Kaburachi J, Stollar B D. Identification of human anti-DNA, anti-RNP, anti-Sm and anti-SSA serum antibodies bearing the cross-reactive 16/6 idiotype. J Immunol 1987; 139: 385-92. 